\title{
Sulfamethoxazole sorption in eutrophic Regolithic Neosol
}

\author{
Márcia A. M. F. de Barros ${ }^{1}$, Antônio C. D. Antoninoํㄹ Alexandre R. P. Schuler², \\ José R. de S. Lima ${ }^{3}$, Manuella V. S. Gondim ${ }^{1} \&$ Valmir F. de Lima ${ }^{2}$
}

\begin{abstract}
${ }^{1}$ Universidade Federal de Pernambuco/Centro de Tecnologia e Geociências/Departamento de Energia Nuclear. Recife, PE. E-mail: marcia_mendel@hotmail.com - ORCID: 0000-0001-7425-8774; acdantonino@gmail.com - ORCID: 0000-0002-4120-9404; manuellavirginia@yahoo.com.br - ORCID: 0000-0002-7317-1885 (Corresponding author)

${ }^{2}$ Instituto Nacional do Semiárido. Campina Grande, PB. E-mail: schulerufpe@gmail.com - ORCID: 0000-0001-7655-8922; atrazina@gmail.com - ORCID: 0000-0003-0280-1533

${ }^{3}$ Universidade Federal Rural de Pernambuco/Unidade Acadêmica de Garanhuns. Garanhuns, PE. E-mail: romualdo_solo@yahoo.com.br - ORCID: 0000-0003-2983-4650
\end{abstract}

\section{Key words:}

soil contamination

interaction

adsorption

\begin{abstract}
A B S T R A C T
This study aimed to evaluate sulfamethoxazole sorption kinetics and isotherms using batch method. The experiment was carried out in typic eutrophic Regolithic Neosol (0-20 and 20$60 \mathrm{~cm}$ layers) located in the private reserve of the Riacho do Papagaio farm, in São João, PE, Brazil. The tests were carried out under laboratory conditions at $24^{\circ} \mathrm{C}$ and sulfamethoxazole concentration was determined by high-performance liquid chromatography. The sorption experiment through the batch method used sulfamethoxazole solutions with concentrations of $10^{-3}, 5.10^{-4}, 10^{-4}, 5.10^{-5}, 10^{-5}$ and $5.10^{-6} \mathrm{~mol} \mathrm{~L}^{-1}$ to obtain the analytical curve. For this soil, sulfamethoxazole sorption kinetics was best described by a second-order model and the sorption isotherms were linear. Sulfamethoxazole predominantly interacts with organic matter in this type of soil. The results obtained in this study show that the antibiotic sulfamethoxazole exhibits low adsorption, posing a higher risk of contamination to the groundwaters in this region at $\mathrm{pH} \approx 7$.
\end{abstract}

\section{Palavras-chave:}

contaminação do solo interação adsorção

\section{Sorção do sulfametoxazol em Neossolo Regolítico eutrófico}

\begin{abstract}
R E S U M O
Objetivou-se neste estudo avaliar a sorção do sulfametoxazol, onde a cinética e as isotermas de sorção foram determinadas em duas camadas de solo Neossolo Regolítico Eutrófico típico (camadas 0-20 e 20-60 cm) da reserva particular da fazenda Riacho do Papagaio, São João, PE. Os ensaios foram realizados em laboratório a $24^{\circ} \mathrm{C}$, pelo método "batch", e a concentração de sulfametoxazol determinada por cromatografia líquida de alta eficiência. Nos ensaios de cinética de sorção foi utilizada solução de sulfametoxazol na concentração de $10^{-4} \mathrm{~mol} \mathrm{~L}^{-1}$, enquanto para as isotermas de sorção foram utilizadas soluções nas concentrações de $10^{-3}, 5.10^{-4}, 10^{-4}, 5.10^{-5}, 10^{-5}$ e $5.10^{-6} \mathrm{~mol} \mathrm{~L}^{-1}$. Para esse solo, as cinéticas de sorção do sulfametoxazol foram melhor descritas com um modelo de segunda ordem e as isotermas de sorção foram lineares. Para este tipo de solo, a interação do sulfametoxazol é predominantemente com a matéria orgânica, apresentando baixa adsorção, evidenciando um maior risco de contaminação das águas subterrâneas existentes nessa região em $\mathrm{pH} \approx 7$.
\end{abstract}




\section{INTRODUCTION}

The environmental impacts resulting from human activities lead to soil degradation and, consequently, to the loss of its capacity to support the activities and/or natural processes (Pejon et al., 2013). These impacts have been intensified in the last decades due to a series of factors, including the use of agrochemicals and pharmaceuticals (Vaz et al., 2007).

Sulfonamides and their derivatives with antimicrobial action are a group of antibiotics mostly used due to their prolonged action, high efficiency, low toxicity and low cost (Morel et al., 2014), and sulfamethoxazole (SMX) is one of them. This compound is indicated in the treatment of urinary tract infections and can be used as an alternative to penicillin in the treatment of sinusitis and to treat toxoplasmosis, being used in both human medicine and veterinary. For Leal et al. (2013), sulfonamides have low sorption in soils and tend to have high potential of leaching, being found in groundwaters. Recent studies in Brazil have detected presence of SMX in sanitary sewage within a concentration range from 1.9 to $151 \mathrm{ng} \mathrm{L}^{-1}$ (Queiroz et al., 2012) and in effluents from sewage treatment station, within concentration ranges from 1.9 to $24 \mathrm{ng} \mathrm{L}^{-1}$ (Brandt, 2012) and from 1.9 to $161 \mathrm{ng} \mathrm{L}^{-1}$ (Queiroz et al., 2012).

Understanding the mechanisms involved in the transport and interactions of chemical compounds in the soils is important for prevention and control of environmental impacts (Milfont et al., 2008). The knowledge on the SMX molecule capacity to interact with the solid phase and its mobility in soils under natural conditions is incipient in Brazil.

Given the above, this study aimed to evaluate soil-SMX interaction, sorption kinetics and isotherm, in typic eutrophic Regolithic Neosol, a soil representative of the Southern Agreste region and characterized by having a not-too-thick mineral and organic material, without presence of diagnostic horizon, in the municipality of São João, PE, in the semi-arid region of Northeast Brazil.

\section{Material ANd Methods}

Sulfamethoxazole [4-Amino-N-(5-methyl-3-isoxazolyl) benzenesulfonamide], CAS 723-46-6, fusion range of $168-172{ }^{\circ} \mathrm{C}$, vapor pressure at $25^{\circ} \mathrm{C}$ of $6.93 \times 10^{-8} \mathrm{mmHg}$, dissociation constants $\mathrm{pKa} 1=1.6$ and $\mathrm{pKa} 2=5.7$, water/ethanol partition coefficient of 0.89 , low solubility at $25^{\circ} \mathrm{C}$ in water, ethanol (1:50) and acetone (1:3); it dissolves in hydrochloric acid or in a sodium hydroxide solution by forming a soluble salt. The sulfamethoxazole used was purchased from Sigma Aldrich with $99.8 \%$ purity.

The solution with common concentration $25.328 \mathrm{~g} \mathrm{~L}^{-1}$ $\left(10^{-1} \mathrm{~mol} \mathrm{~L}^{-1}\right)$ of pure sulfamethoxazole in alcoholic medium was prepared using $2.53 \mathrm{~g}$ of SMX dissolved in $100 \mathrm{~mL}$ of ethanol. Aliquots were then collected to prepare the solutions with the desired concentrations by diluting the initial solution.

The soil, classified as typic eutrophic Regolithic Neosol (Alves, 2015), was collected in a pasture area of the private natural reserve of the Riacho do Papagaio farm, in the municipality of São João, PE, located in the Garanhuns microregion, in Northeast Brazil. The geographic coordinates of the experimental area are $8^{\circ} 48^{\prime} 30^{\prime \prime} \mathrm{S}$ and $36^{\circ} 24^{\prime} 00^{\prime \prime} \mathrm{W}$, at $687 \mathrm{~m}$ above the sea level.

Soil samples were collected in the 0-20 and 20-60 cm layers. Then, the samples were air-dried, pounded to break up clods, sieved through a $2-\mathrm{mm}$ mesh and stored at room temperature. Granulometric analysis was carried out through the hydrometer method. Clay and silt fractions were determined by sedimentation, whereas sand fraction was obtained by sieving, according to the methodology of Loveland \& Whalen (2000). The chemical parameters of interest were $\mathrm{pH}$ in $\mathrm{H}_{2} \mathrm{O}$ and total organic carbon (TOC), determined according to EMBRAPA (1997). Soil layers were analysed according to EMBRAPA (1997) and the results of physical and chemical characteristics of this soil are presented in Table 1.

Sorption kinetics was conducted at $24^{\circ} \mathrm{C}$, in 100 - $\mathrm{mL}$ amber glass container using the procedure described by Martins \& Mermoud (1998), with SMX concentration of $10^{-4} \mathrm{~mol} \mathrm{~L}-1$. Soil-solution ratio was 1:10 (5 g of sample for $50 \mathrm{~mL}$ of SMX solution). The containers were placed on orbital shaker at $200 \mathrm{rpm}$, at preestablished time intervals $(0 ; 0.17 ; 0.33 ; 0.5$; $0.67 ; 0.83 ; 1 ; 2 ; 3 ; 4 ; 5 ; 6 ; 8 ; 12 ; 24 ; 48 \mathrm{~h})$ and 5 -mL aliquots were collected. After centrifugation at $10,000 \mathrm{rpm}$ for $10 \mathrm{~min}$ and filtration in PVDF membranes $(0.45 \mu \mathrm{m}$ pore diameter $)$, SMX concentration was determined by high-performance liquid chromatography (HPLC). The other chromatographic conditions were: $1 \mathrm{~mL} \mathrm{~min}^{-1}$ flow rate of mobile phase $(20 \%$ acetonitrile, $20 \%$ methanol and $60 \%$ distilled water with $\mathrm{pH}$ 3 adjusted with formic acid); UV detection at $267 \mathrm{~nm}$; C18 column $(150 \times 2 \mathrm{~mm} \times 5 \mu \mathrm{m})$ and injected sample volume of $20 \mu \mathrm{L}$.

In $100-\mathrm{mL}$ amber glass containers, $5 \mathrm{~g}$ of sample and SMX solution at $10^{-4} \mathrm{~mol} \mathrm{~L}^{-1}$ concentration were added and its $\mathrm{pH}$ values were adjusted to $1,2,3,4,5,6,7,8$ and 12 , by $0.1 \mathrm{~mol} \mathrm{~L}^{-1}$ $\mathrm{HNO}_{3}$ and $0.1 \mathrm{~mol} \mathrm{~L}^{-1} \mathrm{NaOH}$ solutions, maintaining a final volume of $50 \mathrm{~mL}$, to guarantee the $1: 10$ ratio ( $5 \mathrm{~g}$ of sample and $50 \mathrm{~mL}$ of SMX solution) and allow for a better reading by the device. The $\mathrm{pH}$ of each sample was measured by the potentiometric method using a $\mathrm{pH}$ meter previously calibrated using buffer solutions with $\mathrm{pH} 4.0,7.0$ and 9.0. After agitation for $24 \mathrm{~h}$ on orbital shaker at $200 \mathrm{rpm}$, at $24^{\circ} \mathrm{C}$, the $\mathrm{pH}$ of each sample was measured again and then $5 \mathrm{~mL}$ were collected from each system for centrifugation at 10,000 rpm for $10 \mathrm{~min}$, for a subsequent analysis by HPLC.

The adsorption isotherm, using the method described by Martins \& Mermoud (1998), was carried out in 100-mL amber

Table 1. Characterization of the samples of typic eutrophic Regolithic Neosol (0-20 and 20-60 cm) used in the tests

\begin{tabular}{|c|c|c|c|c|c|c|c|}
\hline \multirow{2}{*}{$\begin{array}{l}\text { Pasture soil } \\
\text { (cm) }\end{array}$} & \multicolumn{3}{|c|}{ Granulometric fraction $\left(\mathrm{g} \mathrm{kg}^{-1}\right)$} & \multirow{2}{*}{ Texture } & \multirow{2}{*}{$\begin{array}{c}\rho \\
\left(\mathrm{kg} \mathrm{dm}^{-3}\right)\end{array}$} & \multirow{2}{*}{$\mathrm{pH}_{\mathrm{H}_{2} \mathrm{O}}$} & \multirow{2}{*}{$\begin{array}{l}\text { TOC } \\
\left(\mathrm{g} \mathrm{kg}^{-1}\right)\end{array}$} \\
\hline & Sand & Silt & Clay & & & & \\
\hline $0-20$ & 853.3 & 123.3 & 23.4 & Loamy sand & 1.507 & 5.9 & $7.32 \pm 0.71$ \\
\hline $20-60$ & 781.9 & 171.2 & 46.9 & Loamy sand & 1.692 & 5.2 & $5.71 \pm 0.35$ \\
\hline
\end{tabular}

*TOC - Total organic carbon; $\rho$ - Global density 
glass containers, respecting the 1:10 ratio, i.e., $5 \mathrm{~g}$ of sample and $50 \mathrm{~mL}$ of SMX solutions at the following molar concentrations $\left(C_{0}\right): 10^{-3} ; 5.10^{-4} ; 10^{-4} ; 5.10^{-5} ; 10^{-5} ; 5.10^{-6}$. The samples were agitated at $200 \mathrm{rpm}$ on orbital shaker for $24 \mathrm{~h}$ to reach equilibrium at the temperature of $24^{\circ} \mathrm{C}$. After centrifugation at $10,000 \mathrm{rpm}$ for $10 \mathrm{~min}$ and filtration in PVDF membranes $(0.45 \mu \mathrm{m}$ pore diameter $)$, the samples were analyzed by HPLC, using the same conditions described for the sorption kinetics. The sorbed SMX concentration (S) was obtained by the expression 1, in which $S$ is the SMX fraction sorbed by the soil $\left(\mathrm{mg} \mathrm{kg}^{-1}\right) ; \mathrm{C}_{0}$ is the initial SMX concentration put in contact with the soil $\left(\mathrm{mg} \mathrm{L}^{-1}\right)$; $\mathrm{C}_{\mathrm{e}}$ is the SMX concentration in the solution after equilibrium $\left(\mathrm{mg} \mathrm{L}^{-1}\right)$ and $\mathrm{DF}$ is the dilution factor, considering the solution:soil ratio.

$$
\mathrm{S}=\left(\mathrm{C}_{0}-\mathrm{C}_{\mathrm{e}}\right) \mathrm{DF}
$$

At concentrations in the environment, adsorption isotherms of organic compounds in the soil can be considered linear, thus being represented by the expression 2 , in which $\mathrm{S}$ is the adsorbed fraction $\left(\mathrm{M} \mathrm{M}^{-1}\right), \mathrm{C}_{\mathrm{e}}$ is the concentration of the chemical substance in the liquid phase $\left(\mathrm{L}^{3} \mathrm{M}^{-1}\right)$ and $\mathrm{K}_{\mathrm{D}}$ is the soil-solution partition coefficient $\left(\mathrm{L}^{3} \mathrm{M}^{-1}\right)$.

$$
\mathrm{S}=\mathrm{K}_{\mathrm{D}} \mathrm{C}_{\mathrm{e}}
$$

According to Yaneva \& Koumanova (2006), sorption kinetics can be mathematically represented by a first-order model:

$$
\frac{\mathrm{dS}_{\mathrm{t}}}{\mathrm{dt}}=\mathrm{k}_{1}\left(\mathrm{~S}_{\mathrm{el}}-\mathrm{S}_{\mathrm{t}}\right)
$$

in which $\mathrm{S}_{\mathrm{e} 1}$ corresponds to the sorption capacity in equilibrium, $\mathrm{S}_{\mathrm{t}}$ corresponds to the sorption capacity at a certain time $\mathrm{t}\left(\mathrm{mg} \mathrm{kg}^{-1}\right)$, and $\mathrm{k}_{1}$ is the first-order sorption constant rate $\left(\mathrm{h}^{-1}\right)$.

Applying the limits $\mathrm{t}=0$ to $\mathrm{t}=\mathrm{t}$ and $\mathrm{S}_{\mathrm{t}}=0$ to $\mathrm{S}_{\mathrm{t}}=\mathrm{S}_{\mathrm{t}}$, after integration, yields:

$$
\log \left(\mathrm{S}_{\mathrm{el}}-\mathrm{S}_{\mathrm{t}}\right)=\log \mathrm{S}_{\mathrm{el}}-\frac{\mathrm{k}_{1}}{2.303} \mathrm{t}
$$

where $k_{1}$ is the adsorption velocity constant and will be obtained by linear regression between $\log \left(\mathrm{S}_{\mathrm{e} 1}-\mathrm{S}_{\mathrm{t}}\right)$ and $\mathrm{t}$.

Yaneva \& Koumanova (2006) describe the sorption rate for a second-order mechanism as:

$$
\frac{\mathrm{dS}_{\mathrm{t}}}{\mathrm{dt}}=\mathrm{k}_{2}\left(\mathrm{~S}_{\mathrm{e} 2}-\mathrm{S}_{\mathrm{t}}\right)^{2}
$$

where $S_{e_{2}}$ and $S_{t}$ are, respectively, sorption capacity in equilibrium and sorption capacity at time $\mathrm{t}\left(\mathrm{mg} \mathrm{kg}^{-1}\right)$, and $\mathrm{k}_{2}$ is the secondorder sorption constant rate $\left(\mathrm{kg} \mathrm{kg}^{-1} \mathrm{~h}^{-1}\right)$. Applying the limits $\mathrm{t}=$ 0 to $\mathrm{t}=\mathrm{t}$ and $\mathrm{S}_{\mathrm{t}}=0$ to $\mathrm{S}_{\mathrm{t}}=\mathrm{S}_{\mathrm{t}}$, and integrating, leads to:

$$
\frac{1}{\mathrm{~S}_{\mathrm{e} 2}-\mathrm{S}_{\mathrm{t}}}=\frac{1}{\mathrm{~S}_{\mathrm{e} 2}}+\mathrm{k}_{2} \mathrm{t}
$$

which, if linearly rearranged, yields:

$$
\frac{\mathrm{t}}{\mathrm{S}_{\mathrm{t}}}=\frac{1}{\mathrm{k}_{\mathrm{S}}}+\frac{1}{\mathrm{~S}_{\mathrm{e} 2}} \mathrm{t} \text { with } \mathrm{k}_{\mathrm{S}}=\mathrm{k}_{2} \mathrm{~S}_{\mathrm{e} 2}^{2}
$$

where $\mathrm{k}_{\mathrm{s}}$ can be considered as the initial sorption rate when $\left(\mathrm{S}_{\mathrm{t}} / \mathrm{t}\right) \rightarrow 0$

\section{Results AND Discussion}

SMX sorption kinetics in the typic eutrophic Regolithic Neosol is presented in Figure 1. Equilibrium between SMX in solution and SMX adsorbed to the soil was reached after $12 \mathrm{~h}$ of contact between soil and solution, and the 0-20 cm layer adsorbed greater amount of SMX, about $69 \mathrm{mg} \mathrm{kg}^{-1}$, whereas the 20-60 cm layer adsorbed approximately $40 \mathrm{mg} \mathrm{kg}^{-1}$.

In the $0-20 \mathrm{~cm}$ layer, $\mathrm{R}^{2}$ values for the first-order kinetics (0.9761) were slightly lower than those for the second-order kinetics (0.9879), indicating that the second-order sorption kinetics showed better fit to the data of the studied soil (Table 2). In the 20-60 cm layer, the second-order kinetics also showed better fit, but larger difference was found between $\mathrm{R}^{2}$ values (0.8176 and 0.9974$)$. Values of sorption capacity in equilibrium were: $S_{\text {e }}$ equal to 60.85 and 20.05 for the $0-20$ and $20-60 \mathrm{~cm}$ layers, respectively, and $S_{\mathrm{e} 2}$ equal to 75.75 and 41.66 for the $0-20$ and $20-60 \mathrm{~cm}$ layers, respectively (Table 2 ). Initial sorption rate values, ks, were 17.22 and $50.35 \mathrm{mg} \mathrm{kg}^{-1} \mathrm{~h}^{-1}$ for the $0-20$ and 20-60 cm layers, respectively.

Clay minerals and soil organic matter can weakly or strongly adsorb organic molecules, depending on the sorption mechanism and on adsorbent-adsorbate interaction forces (Milfont et al., 2007). Studies conducted in soils have confirmed that SMX is adsorbed by the organic matter and minerals of the clay fraction, but not by the sand fraction and gravels composing the soil, as observed by Hou et al. (2010), who demonstrated that SMX has high sorption in organic fractions (humic acids) and in mineral inorganic particles, but low sorption in the particles of the original sediments of a soil. In the $0-20$ and $20-60 \mathrm{~cm}$ layers of the eutrophic

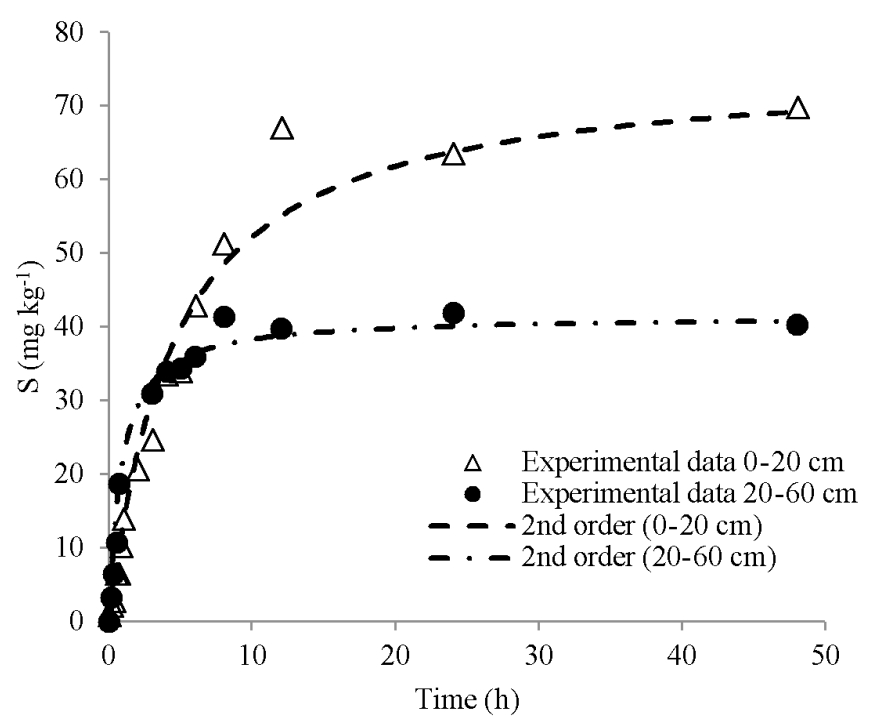

Figure 1. Sulfamethoxazole (SMX) sorption kinetics in typic eutrophic Regolithic Neosol 
Table 2. Sorption capacity in equilibrium, $\mathrm{S}_{\mathrm{e} 1}$ and $\mathrm{S}_{\mathrm{e} 2}$; sorption constant rate, $\mathrm{K}_{1}$ and $\mathrm{K}_{2}$; and coefficient of determination, $\mathrm{R}^{2}$, for both models in two soil layers

\begin{tabular}{|c|c|c|c|}
\hline \multirow{2}{*}{$\begin{array}{l}\text { Soil layer } \\
\text { (cm) }\end{array}$} & \multicolumn{2}{|c|}{ Sorption } & \multirow{2}{*}{$\begin{array}{c}\text { Coefficient } \\
\text { of determination }\end{array}$} \\
\hline & Capacity & Rate & \\
\hline \multicolumn{4}{|c|}{ First-order kinetics $-\left(\mathrm{dS}_{\mathrm{V}} / \mathrm{dt}\right)=\mathrm{K}_{1}\left(\mathrm{~S}_{\mathrm{e} 1}-\mathrm{S}_{\mathrm{t}}\right)$} \\
\hline & $\mathrm{S}_{\mathrm{e} 1}\left(\mathrm{mg} \mathrm{kg}^{-1}\right)$ & $K_{1}\left(h^{-1}\right)$ & $\mathrm{R}^{2}$ \\
\hline $0-20$ & 60.855 & 0.128 & 0.9761 \\
\hline $20-60$ & 20.054 & 0.09 & 0.8176 \\
\hline \multicolumn{4}{|c|}{ Second-order kinetics $-(\mathrm{dS} / \mathrm{dt})=\mathrm{K}_{2}\left(\mathrm{~S}_{\mathrm{e} 2}-\mathrm{S}_{\mathrm{t}}\right)^{2}$} \\
\hline & $\mathrm{S}_{\mathrm{e} 2}\left(\mathrm{mg} \mathrm{kg}^{-1}\right)$ & $\mathrm{K}_{2}\left(\mathrm{~kg} \mathrm{mg}^{-1} \mathrm{~h}^{-1}\right)$ & $\mathrm{R}^{2}$ \\
\hline $0-20$ & 75.757 & 0.003 & 0.9879 \\
\hline $20-60$ & 41.667 & 0.029 & 0.9974 \\
\hline
\end{tabular}

Regolithic Neosol, sorption is closely related to the organic matter content, since it was higher in the superficial layer, where higher contents of organic matter are found.

Since $\mathrm{pH}$ is an important factor affecting SMX availability in the soil, where the antibiotic becomes less available with the increment in the $\mathrm{pH}$ of the solution, it was found experimentally that SMX solubility varies according to the change in the $\mathrm{pH}$ of the medium. For Barriuso et al. (1992), the effect of $\mathrm{pH}$ can be responsible for organic matter solubilization, thus increasing water solubility of compounds. The results of sorption as a function of the $\mathrm{pH}$ of SMX are presented in Figure 2. Sorption varied according to $\mathrm{pH}$, and the mechanism of SMX adsorption in the soil plays an insignificant role at $\mathrm{pH} \approx 7$, due to the electrostatic repulsion between the negatively charged groups of the compound and the negatively charged surface of soil particles. This is related to the pKa values of SMX (1.6 and 5.7), so that the antibiotic will be predominantly present as a neutral species with $\mathrm{pH}$ between its $\mathrm{pKa}$ values. On the other hand, in solution with $\mathrm{pH}$ above its pKa2 (5.7), SMX becomes a negatively charged chemical species, as can be seen in Figure 3. This is in agreement with Lertpaitoonpan et al. (2009), Biatk-Bielińska et al. (2012) and Leal et al. (2013), who studied the sorption of sulfonamides and found that, as $\mathrm{pH}$ increases, their sorption decreases due to the ionization of the molecules. Anionic species are less sorbed than neutral species, and the latter exhibit low sorption compared with cationic species, due the electrostatic interaction between the ionic species and soil particles.

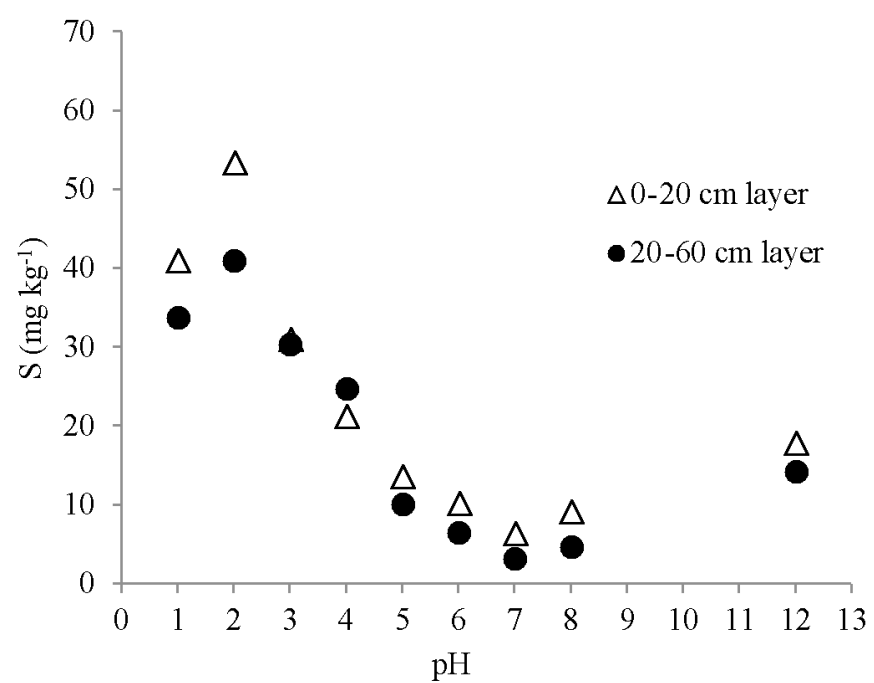

Figure 2. Sulfamethoxazole (SMX) sorption as a function of $\mathrm{pH}$ in typic eutrophic Regolithic Neosol

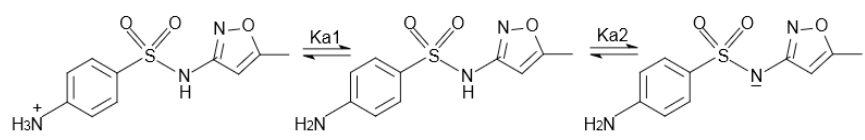

$\mathrm{SH}_{2}^{+}$

$\mathrm{SH}$

$\mathrm{s}^{-}$

Figure 3. Acid-base equilibrium of SMX in aqueous solution. $\mathrm{SH}_{2}{ }^{+}$- cationic form, protonated; $\mathrm{SH}$ - Neutral form and $\mathrm{S}^{-}$- Anionic form, deprotonated

For Sposito (2008), soil solution $\mathrm{pH}$ is one of the main characteristics governing the solid-liquid interactions of ionizable molecules and causes variation in the solubility of non-ionizable molecules, modifying the charge of mineral or organic surfaces, thus determining the preponderant interaction mechanism. SMX molecules $(\mathrm{pKa} 2=5.7)$ are more negatively charged at $\mathrm{pH}=6.9-7.3$, leading to a substantial increase in hydrophilicity compared with neutral species. Conversely, neutral SMX species are more dominant at $\mathrm{pH}=$ 2 , and are the most hydrophobic ones (Lian et al., 2014), thus demonstrating an optimal $\mathrm{pH}$ to prevent greater displacement of SMX. Nonetheless, this not the $\mathrm{pH}$ of the soil in this region, which is between 5.6-6.4. Consequently, SMX hydrophilicity increases and its risk of contamination rises, because there is a reduction in its sorption.

SMX adsorption results in alkalinization of its samples at $\mathrm{pKa}$ lower than 7 and acidification at $\mathrm{pKa}$ higher than 7 , remaining unchanged at $\mathrm{pH}=12$. This does not agree with Nielsen et al. (2014), who claimed that SMX adsorption apparently results in acidification of its samples and the most accentuated alterations are visible at $\mathrm{pKa}$ higher than 7 . This occurs most likely because these acids were introduced to the surface probably due to the amino group of the sulfonamide radical. In addition, one may also accept the idea that the oxidation of sulfones in sulfonic acids causes reduction in the $\mathrm{pH}$ of the system.

SMX sorption isotherms for the 0-20 and 20-60 cm layers are presented in Figure 4, in which a linear model fitted to the data.

The 0-20 cm layer showed greater SMX sorption compared with the $20-60 \mathrm{~cm}$ layer, although the latter had a slightly higher clay fraction than the superficial layer. This indicates that there is almost no interaction of clay minerals with SMX, especially hydrophobic, which could occur with neutral microsites of any mineral, confirming that the more hydrophobic the

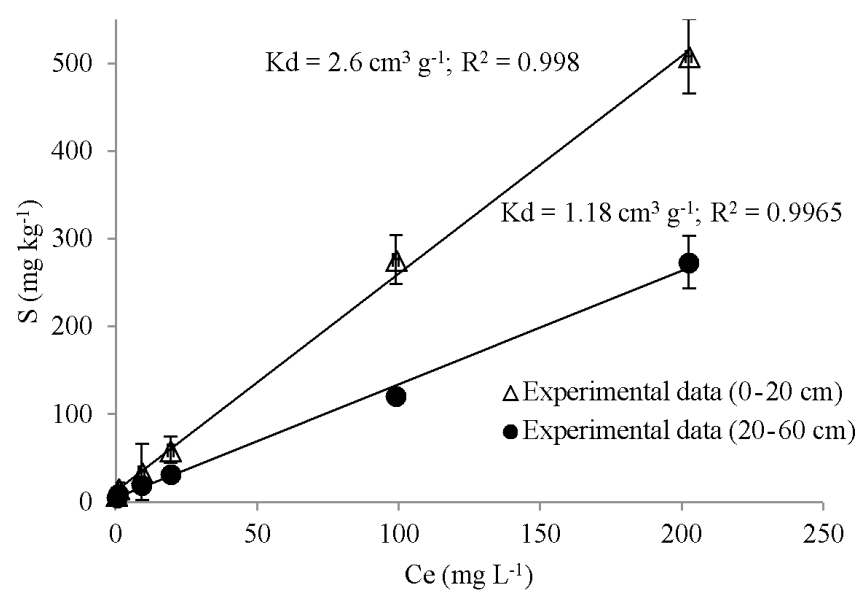

Figure 4. Sulfamethoxazole (SMX) sorption isotherms in typic eutrophic Regolithic Neosol in the 0-20 and 20-60 $\mathrm{cm}$ layers, fitted to a linear model 
molecule, the smaller its interaction with clay. This type of interaction leads to physical adsorption, characterized by being weak and reversible, in which the equilibrium of adsorbed and non-adsorbed forms is rapidly established. Possible hydrophilic interactions of SMX with organic matter occur through hydrogen bonds between $\mathrm{NH}_{2}$ (amino) groups and possible oxidation of sulfones in sulfonic acid, with carboxyl groups and/or carboxylates of organic matter. This type of intermolecular interaction is stronger than the hydrophobic one, but continues to be reversible; however, the equilibrium is established more slowly. Due to the possible points of formation of hydrogen bonds in the SMX molecule, this type of interaction becomes predominant with the organic matter when it has ionized carboxyl groups.

\section{Conclusions}

1. In typic eutrophic Regolithic Neosol, sulfamethoxazole sorption kinetics is best described by a second-order model, and sorption isotherms are linear.

2. Sulfamethoxazole sorption is low in this type of soil, being slightly higher in the superficial layer $(0-20 \mathrm{~cm})$, due to greater amount of organic matter.

3. At $\mathrm{pH} \approx 7$, there is a reduction in sulfamethoxazole sorption in both soil layers, because this compound is found in the form of its anionic species, being repelled by the soil particle surface, which is also negatively charged.

4. To reduce SMX leaching, organic fertilization is recommended in these soils to increase the amount of organic matter and, consequently, reduce the risks of contamination of surface and subsurface waters.

\section{Literature Cited}

Alves, E. M. Fluxos de energia, vapor d'água e $\mathrm{CO}_{2}$ entre a vegetação e a atmosfera no agreste meridional de Pernambuco. Recife: Universidade Federal de Pernambuco, 2015. 96p. Tese Doutorado

Barriuso, E.; Baer, U.; Calvet, R. Dissolved organic matter and adsorption-desorption of dimefuron, atrazine, and carbetamide by soils. Journal of Environmental Quality, v.21, p.359-367, 1992. https://doi.org/10.2134/jeq1992.00472425002100030009x

Biatk-Bielińska, A.; Maszkowska, J.; Mrozik, W.; Bielawska, A.; Kolodziejska, M.; Palavinskas, R.; Stepnowski, P.; Kumirska, J. Sulfadimethoxine and sulfaguanidine: Their sorption on natural soils. Chemosphere, v.86, p.1059-1065, 2012. https://doi. org/10.1016/j.chemosphere.2011.11.058

Brandt, E. M. F. Avaliação da remoção de fármacos e desreguladores endócrinos em sistemas simplificados de tratamento de esgoto (reatores UASB seguidos de pós-tratamento). Belo Horizonte: Universidade Federal de Minas Gerais, 2012. 128p. Dissertação Mestrado

EMBRAPA - Empresa Brasileira de Pesquisa Agropecuária. Manual de métodos de análise do solo. 2.ed. Rio de Janeiro: Embrapa Solos, 1997. 212p.

Hou, J.; Pan, B.; Niu, X.; Chen, J.; Xing, B. Sulfamethoxazole sorption by sediment fractions in comparison to pyrene and bisphenol $\mathrm{A}$. Environmental Pollution, v.158, p.2826-2832, 2010. https://doi. org/10.1016/j.envpol.2010.06.023
Leal, R. M. P.; Alleoni, L. R. F.; Tornisielo, V. L.; Regitano, J. B. Sorption of fluoroquinolones and sulfonamides in 13 Brazilian soils. Chemosphere, v.92, p.979-985, 2013. https://doi.org/10.1016/j. chemosphere.2013.03.018

Lertpaitoonpan, W.; Ong, S. K.; Moorman, T. B. Effect of organic carbon and $\mathrm{pH}$ on soil sorption of sulfamethazine. Chemosphere, v.76, p.558-564, 2009. https://doi.org/10.1016/j. chemosphere.2009.02.066

Lian, F.; Sun, B.; Song, Z.; Zhu, L.; Qi, X.; Xing, B. Physicochemical properties of herb-residue biochar and its sorption to ionizable antibiotic sulfamethoxazole. Chemical Engineering Journal, v.248, p.128-134, 2014. https://doi.org/10.1016/j.cej.2014.03.021

Loveland, P. J.; Whalen, W. R. Particle size analysis. In: Smith, K. A.; Mullis, C. E. Soil and environmental analysis: Physical methods. 2.ed. rev. exp. New York: Marcel Dekker, 2000. Chap.7, p.281-314. https://doi.org/10.1201/9780203908600.ch7

Martins, J. M. F.; Mermoud, A. Sorption and degradation of four nitroaromatic herbicides in mono and multi-solute satured/unsatured soil batch systems. Journal of Contaminant Hydrology, v.33, p.187-210, 1998. https://doi.org/10.1016/S01697722(98)00070-9

Milfont, M. L.; Antonino, A. C. D.; Martins, J. M. F.; Maciel Netto, A.; Gouveia, E. R.; Freire, M. B. G. dos S. Sorção do paclobutrazol em dois solos cultivados com manga irrigada. Revista Brasileira de Ciências Agrárias, v.2, p.285-291, 2007. https://doi.org/10.5039/ agraria.v2i4a1928

Milfont, M. L.; Martins, J. M. F.; Antonino, A. C. D.; Gouveia, E. R.; Maciel Netto, A.; Freire, M. B. G. dos S. Reactivity of the plant growth regulator paclobutrazol (cultar) with two tropical soils of the northeast semiarid region of Brazil. Journal of Environmental Quality, v.37, p.90-97, 2008. https://doi.org/10.2134/jeq2007.0210

Morel, M. C.; Spadini, L.; Brimo, K.; Martins, J. M. F. Speciation study in the sulfamethoxazole-copper-pH-soil system: Implications for retention prediction. Science of the Total Environment, v.481, p.266-273, 2014. https://doi.org/10.1016/j.scitotenv.2014.02.040

Nielsen, L.; Biggs, M. J.; Skinner, W.; Bandosz, T. J. The effects of activated carbon surface features on the reactive adsorption of carbamazepine and sulfamethoxazole. Carbon, v.80, p.419-432, 2014. https://doi.org/10.1016/j.carbon.2014.08.081

Pejon, O. J.; Rodrigues, V. G. S.; Zuquette, L. V. Impactos ambientais sobre o solo. In: Calijuri, M. C.; Cunha, D. G. F. Engenharia Ambiental: Conceitos, tecnologia e gestão. 1.ed. São Paulo: Campus-Elsevier, 2013. Cap.14, p.317-343.

Queiroz, F. B.; Brandt, E. M. F.; Aquino, S. F.; Chernicharo, C. A. L.; Afonso, R. J. C. F. Occurrence of pharmaceuticals and endocrine disruptors in raw sewage and their behavior in UASB reactors operated at different hydraulic retention times. Water Science \& Technology, v.66, p.2562-2569, 2012. https://doi.org/10.2166/ wst.2012.482

Sposito, G. The chemistry of soils. New York: Oxford University Press, 2008. 344p.

Vaz, F. L.; Milfont, M. L. B.; Souto-Maior, A. M.; Gouveia, E. R. Determinação da concentração de paclobutrazol por cromatografia líquida de alta eficiência e espectroscopia. Química Nova, v.30, p.281-283, 2007. https://doi.org/10.1590/S010040422007000200007

Yaneva, Z.; Koumanova, B. Comparative modeling of mono and dinitrophenols sorption on yellow bentonite from aqueous solutions. Journal of Colloid and Interface Science, v.293, p.303311, 2006. https://doi.org/10.1016/j.jcis.2005.06.069 